\title{
Вторжение Исламского государства в Северную Африку и Сахель: угроза для Аль-Каиды?
}

\section{Манни Крон}

Датский институт международных исследований

\begin{abstract}
Резюме: В статье рассматривается экспансия Исламского государства в Северную Африку и Сахель и проистекающее из этого соперничество между Исламским государством и Аль-Каидой в Исламском Магрибе - региональной группировки Аль-Каиды. Хотя ИГ успело создать провинцию в Ливии с 2014 по 2016 год, его присутствие в Северной Африке и Сахели (Ливия, Синай, Нигерия) является весьма неустойчивым. АКИМ, наоборот, давно присутствует в этом регионе, и ее присутствие консолидировано в гораздо большей степени. Соперничество между ИГ и АК в этом регионе заставило отколовшиеся от АК группы объединиться вокруг АКИМ, и в 2016 году эти группировки усилили свои нападения на западные мишени.
\end{abstract}

Ключевые слова: Аль-Каида в Исламском Магрибе, Исламское государство, провинция Синай, Боко Харам, терроризм, Ливия, Северная Африка, Сахель.

\section{Введение}

В настоящее время внимание мировых СМИ остро сфокусировано на деятельности Исламского государства (ИГ) в Ираке и Сирии, где ИГ подвергается возрастающему давлению. Широкая коалиция стран в настоящее время пытается сражаться с ИГ в Ираке и в Сирии и, конкретнее, в городах Мосул и Ракка. Однако ИГ не только добилось присутствия в этих странах. В отличие от Аль-Каиды (АК), которая до последнего времени следовала стратегии создания небольших местных «эмиратов», Халифат ИГ является политическим субъектом, стремящимся к охвату всего мусульманского мира. С момента, когда было заявлено о создании Халифата летом 2014 года, ИГ пытается расширить свою деятельность, создавая так называемые 
«провинции» (вилаяты) в других регионах, и слово “экспансия» само по себе стало идеологическим кодовым словом. Таким образом, местные группировки ИГ возникли в разных местах Азии, Кавказа и в определенных частях Африки. Однако, интересным аспектом всего этого является не только географическая экспансия ИГ, а особая манера, в которой эта экспансия разыгрывается в отношении разных местных групп АК, которые уже присутствуют в разных регионах. Привело ли появление ИГ в этих районах к соперничеству, или к сотрудничеству, или к некоему modus vivendi [временному сосуществованию] между ИГ и АК? И существует ли на деле существенная разница в методах и проектах ИГ и АК, или они являются разными сторонами одной и той же монеты? Чтобы пролить свет на эти вопросы, в данной статье рассматривается только определенная географическая область - Северная Африка и Сахель (фигура 1) - и обрисовывается картина влияния результатов вторжения ИГ в этот регион на динамику региональной безопасности и то, какие последствия имеет такое развитие событий для угрозы, направленной на западные мишени.

\section{Территориальная экспансия ИГ в Северную Африку и Сахель}

Летом 2014 года лидер Исламского государств, Абу Бакр аль-Багдади, объявил о восстановлении классического исламского халифата. Халифат является политическим субъектом, которому в принципе подчиняются все мусульмане и потому он нацелен на охват всей исторической исламской территории в ее целостности от Марокко до Индонезии. На этом фоне не было неожиданным, что вскоре после создания в Ираке и Сирии, новый Халифат начал расширяться за пределы этих регионов, и с самого начала Северная Африка была в начале списка намерений ИГ. Еще в первых номерах журнала ИГ Дабик представитель ИГ не только повторял мантру «экспансия», но и подчеркивал выдающиеся качества близлежащей Ливии. ${ }^{1}$ Не удивительно, что первой официальной провинцией ИГ вне Ирака и Сирии стал ливийский город Дерна, который в октябре 2014 года был присоединен к Халифату под именем «провинция Дерна». Через месяц после этой де факто аннексии Дерны Багдади опубликовал официальный список всех новых провинций ИГ. Кроме анклавов в Йемене и в Саудовской Аравии, в этом списке появились три провинции в Северной Африке: Дерна, Синай и провинция Алжир. В 2015 и 2016 пропаганда ИГ убеждала будущих иностранных боевиков предпочесть Ливию перед Сирией и Ираком, если они вознамеривались присоединиться к ИГ. Из-за возрастающих проблем, связанных с удержанием территорий в Сирии и Ираке, ИГ давно рассматривало Ливию как потенциальный новый фронт, где оно могло бы использовать неустойчивую политическую ситуацию для того, чтобы установиться вблизи границ Европы.

1 “From Hijrah to Khilafah," Dabiq, no. 1 (July 2014), p. 36. 


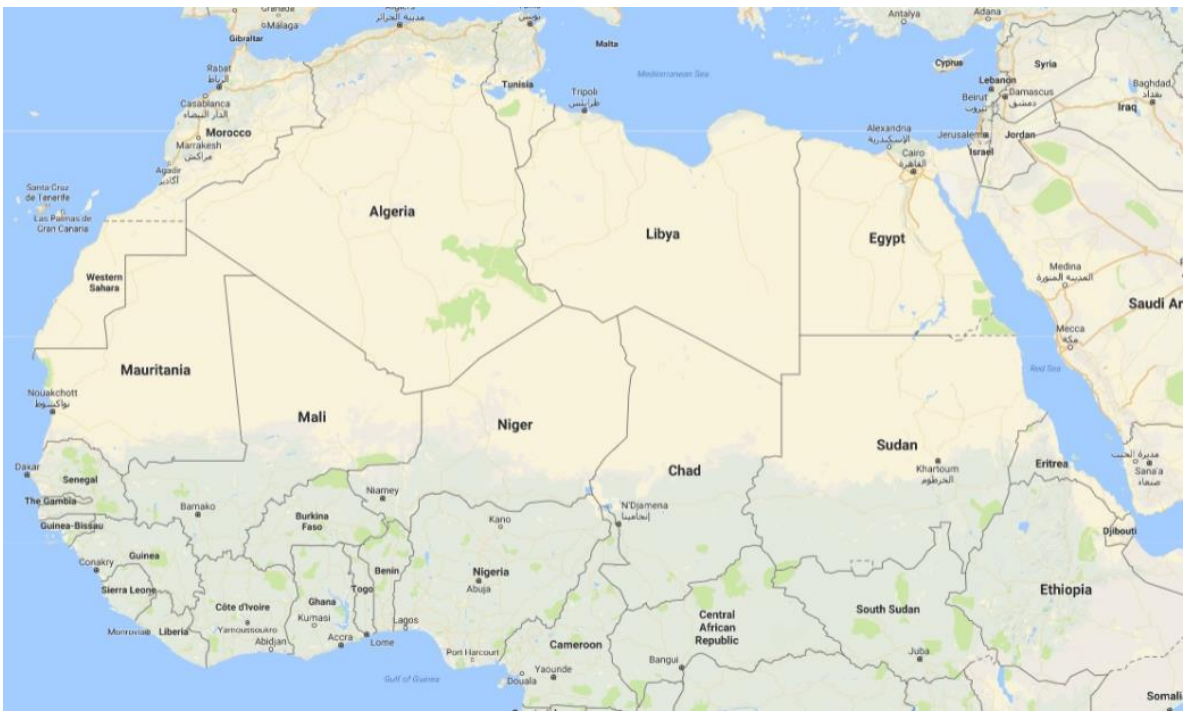

\section{Фигура 1: Карта Северной Африки и Сахели.}

Вне его основных территорий в Сирии и Ираке, одним из опорных пунктов ИГ давно была Ливия. Нет точных чисел, характеризующих степень присутствия ИГ в Ливии, но в одном докладе ООН от 2015 года приведена оценка, что в определенный момент времени в Ливии находились от трех до пяти тысяч боевиков. В 2016 году источники разведки США оценивали это присутствие в 6500 человек, а французская национальная газета Le Monde приводила более консервативную оценку в 5000 человек. Главное тут в том, что надежных чисел нет. Основное присутствие Халифата в Ливии долгое время имело место в так называемой «провинции Сирт», вокруг прибрежного города Сирт, но ИГ, которое в декабре 2016 года было вынуждено уйти из этого района, так же создало и меньшие анклавы, например, в Триполи и в Сабрате. Подобным образом была создана большая провинция на Синайском полуострове в Египте. Однако если не считать Синай, присутствие ИГ в регионе в целом остается спорадическим. В 2015 году вооруженная нигерийская группировка, Боко Харам, объявила, что присоединяется к ИГ, и в связи с этим приняла изменение наименования от Нигерии на «Западноафриканская провинция». Кроме того, большое число маленьких групп по всему региону присягнули на верность (байя) ИГ, но такие декларации о поддержке часто оказываются недолговечными и скоро отзываются, если обстоятельства изменяются.

В некоторых случаях распространение ИГ в Северную Африку/Сахель осуществлялось как стратегия сверху-вниз, при которой Халифат посылал отдельных лиц в этот регион, чтобы они создавали территориальные анклавы. В большинстве случаев, однако, стратегия состояла в том, что 
местные группы заявляли о своей преданности Багдади, и таким образом, они присоединялись к ИГ. Действующие одновременно с ИГ, добивающегося успеха на полях сражений, объявившим о создании Халифата и начавшем распространять свои пропагандистские видеозаписи, показывающие крайнее насилие, многие вооруженные группировки в Северной Африке и Сахели решили присоединиться к ИГ по своей собственной инициативе. Однако, это в целом является сложным, динамическим процессом, при котором вооруженные группировки сначала заявляют, что поддерживают ИГ, и затем в некоторых случаях устанавливают официальные отношения с высокопоставленными эмирами ИГ - или даже получают официальное признание напрямую от самого Багдади. Благодаря факту, что многие иностранные боевики из Северной Африки/Сахели отправлялись в Сирию воевать в поддержку ИГ, стало обычным, что по возвращении в свои родные страны они устанавливали новые контакты с руководящими ИГ эмирами.

\section{Что делает ИГ в Ливии?}

С самого начала Северная Африка была частью территории, которую Халифат ИГ рассматривал как свой доминион, а Ливия, в частности, была одним из его главных приоритетов. ИГ использовало хаотическую политическую ситуацию в Ливии, чтобы закрепиться там и затем консолидировать свое территориальное присутствие. Первым шагом в этом процессе был, как уже упоминалось, захват северного прибрежного города Дерна, который, тем не менее, летом 2015 года ИГ было вынуждено оставить. Несмотря на то, что провинция Дерна уже дело прошлое, тем не менее стоит рассмотреть оккупацию этого города ИГ, поскольку это даст нам понимание того, как ИГ расширяется и занимает новые регионы. Еще в 2013 году Багдади послал представителей в бывший опорный пункт джихадистов город Дерна, чтобы они проверили возможности осуществления экспансии в этот регион. ${ }^{2}$

Вскоре после провозглашения Халифата летом 2014 года, молодежная вооруженная группировка в Дерне присягнула на верность Багдади, и в октябре руководство ИГ послало иракца Абу Набил аль-Анбари в Ливию, чтобы формализовать присоединение города к Халифату. ${ }^{3}$ Абу Набил был опытным боевиком, который под флагом АК воевал в Ираке с 2004 года. Таким образом, учреждение провинции Дерна было решением, принятым на самом высоком уровне в ИГ. Однако, несмотря на факт, что Ливии был присвоен высокий приоритет, местная группировка ИГ - которой оказывало поддержку иракское отделение ИГ - не успела добиться поддержки

2 Geoff D. Porter, "How realistic is Libya as an Islamic State "fallback?"," CTC Sentinel 9, no. 3 (March 2016): 1-5.

3 Ourdan, Rémy, "Derna, premier territoire de l'El hors des frontières du "califat" en Libye", Le Monde (13 November 2014). 
местного населения в Дерне. В июне 2015 года столкновение с местной группировкой, связанной с АК, привело к тому, что ИГ было вынуждено уйти из города.

ИГ столкнулось с разными трудностями в городах Бенгази и Сабрата. В восточной части Бенгази ИГ столкнулось с вооруженным сопротивлением со стороны одного из двух ливийских правительств - правительства Тобрука - в форме нападения войск генерала Хефтара, которые воевали с разными исламистскими милициями в восточной Ливии. В начале 2016 года боевые самолеты США бомбардировали убежище ИГ в прибрежном городе Сабрата в западной Ливии, в котором в числе других проживали большое число иностранных боевиков из Туниса. Главной мишенью этого нападения был гражданин Туниса, который предположительно организовал несколько террористических нападений в соседнем Тунисе.

Таким образом, до декабря 2016 года ИГ в основном имело присутствие в «провинции Сирт» - прибрежном районе, окружающим город Сирт, который в прошлом был одним из оплотов Муаммара Каддафи. В Сирте, весьма парадоксально, путь к оккупации города ИГ проложила местная милиция, связанная с АК, Ансар аль-Шариат. В течении 2014 года Ансар аль-Шариат установилась в Сирте в типичной для АК манере, выпустив дава (прокламацию) и занимаясь благотворительностью. Однако, в отличие от ситуации в Дерне, где ИГ вошло в конфликт с местными милициями, определенные элементы в Ансар аль-Шариат решили присоединиться к ИГ и декларировали свою лояльность Багдади. В период с февраля по май 2015 года ИГ успело захватить контроль над всеми важными институциями в городе: радио, телевидением, иммиграционным центром, университетом и т.д. Никоим образом нельзя пренебрегать фактом, что Сирт является местом рождения Каддафи. В Сирте ИГ смогло использовать недовольство местных милиций, верных Каддафи, политическим развитием в Ливии, которое подорвало их влияние и престиж. Территориальное присутствие ИГ в Сирте дает группировке определенные преимущества. Провинция предоставляет ИГ стратегическую глубину в отношении Сирии и Ирака и возможность потенциального переезда в Ливию, если ИГ будет вынуждено воевать в этих странах. Кроме того, ИГ имеет определенную выгоду от присутствия в районе, который находится близко не только от ливийских нефтяных полей, но и от границ Европы.

Кроме территориального присутствия в провинции Сирт, ИГ располагает более дискретным присутствием в практически всех городах вдоль ливийского берега, в основном в Триполи и в Сабрате. Группировка, называющая себя «провинцией Триполи», регулярно берет на себя ответственность за разные теракты против одного из ливийских правительств. Однако ИГ отнюдь не добилось решительного контроля над данным районом. Скорее ИГ реализовало спорадическое присутствие в конкретных областях или небольших районах, которые оно использует в качестве убежищ или лагерей для подготовки. Эти ливийские анклавы привлекли 
большое число иностранных боевиков, в основном из соседнего Туниса, но также и из других стран Северной Африки и Сахели. В 2015 году в одном докладе ООН приводится оценка, что около 5500 тунисцев присоединились к ИГ, и что 1000-1500 из них находятся в Ливии. ${ }^{4}$ Для жителей Туниса относительно легко пересекать границу с Ливией, где они могут связываться с группами ИГ и получать подготовку. Затем эти иностранные боевики или едут в Сирию, чтобы воевать в поддержку ИГ там, или остаются в Ливии и способствуют консолидации провинции Сирт или других анклавов ИГ в Ливии.

ИГ привлекает в Ливию иностранных боевиков из всей Северной Африки и Сахели, но тунисские боевики ИГ являются особой угрозой для хрупкой тунисской демократии. В нескольких случаях они возвращались в Тунис для совершения терактов и не раз наносили вред туристической отрасли Туниса, которая для этой страны является одним из наиболее важных источников дохода. К примеру, эти иностранные боевики совершили нападение на музей в столице Туниса, а затем на пляжный отель. Однако, наиболее значительный теракт был осуществлен в 2016 году, когда тунисские боевики ИГ, действующие из базы в Ливии, не только попытались осуществить террористическое нападение, но и напрямую попробовали захватить граничный тунисский город Бен-Гардан. ${ }^{5}$ В марте около 100 боевиков ИГ из ливийского города Сабрата, который незадолго до этого подвергся воздушному удару боевых самолетов США, вошли в Тунис и напали на части армии и полиции в Бен-Гардане. Они попытались захватить город, подстрекая жителей к восстанию, что закончилось гибелью 50 боевиков и 20 тунисских солдат.

\section{ИГ в Египте, Нигерии и Сахели}

Кроме как в установлении территориального присутствия в Ливии - и в провалившейся попытке расшириться через тунисскую границу, - Халифат преуспел в создании несчетного числа малых анклавов и провинций в Северной Африке и Сахели. Несмотря на повсеместное использование термина «провинция», который предполагает территориальное измерение, деятельность ИГ в этих областях редко доходит до территориальных прибавлений, как в Сирте, а скорее речь идет о более или менее сформировавшихся группах, пытающихся греться в лучах отраженной славы, заявляя о преданности Багдади, таким образом разделяя большую до недавнего времени популярность ИГ.

4 Savannah de Tessières, Naji Abou-Khalil, Jan Barend Coetzee, Simon Dilloway, Juan Alberto Pintos Servia, and Steven Spittaels, Letter dated 4 March 2016 from the Panel of Experts on Libya established pursuant to resolution 1973 (2011) addressed to the President of the Security Council, UNSC S/2016/209, March 9, 2016, по состоянию на 24 июня 2016, www.un.org/ga/search/view_doc.asp?symbol= S/2016/209.

5 Frédéric Bobin, "La Tunisie au péril de l'État islamique," Le Monde March 3, 2016. 
В ноябре 2014 года на Синайском полуострове египетская повстанческая группировка Ансар Бейт аль-Макдис, которая возникла после Арабской весны, трансформировала себя в «провинцию Синай». ${ }^{6}$ Более того, в октябре 2015 года эта самая «провинция Синай» была в основе теракта против российского пассажирского самолета, осуществленного после того, как Россия начала бомбить ИГ в Сирии. Независимо от этого, основной целью группировки остается, как было заявлено, дестабилизация египетского режима путем совершения нападений на армию и полицию на Синае. В нескольких случаях группировке удалось осуществить нападения на мишени, находящиеся в самом Каире. Теракт против российского самолета показывает, однако, что группировка уже имеет не узко национальную повестку дня, но начала осуществлять нападения под брендом ИГ, хотя и в ограниченной степени.

Однако ИГ не только обеспечило присутствие в Северной Африке. В марте 2015 года нигерийская группировка Боко Харам так же присоединилась к ИГ и потому трансформировала себя в «провинцию в Западной Африке» Исламского государства. Эта метаморфоза из насильственной повстанческой группировки в провинцию ИГ произошла в момент, когда Боко Харам была под значительным давлением из-за того, что силы нигерийского правительства в сотрудничестве с войсками из соседнего Чада, Камеруна, Нигера и Франции начали военное наступление против Боко Харам. Вскоре после этого, официальный представитель ИГ, Аднани, приветствовал Боко Харам в семье ИГ и объявил, что присоединение Боко Харам ясно показывает, что теперь Халифат уже расширяется, чтобы охватить Западную Африку. Давно витали сомнения о том, в какой степени связаны Боко Харам и центральные элементы ИГ. Однако, в августе 2016 года ИГ назначило нового руководителя западно-африканской провинции, Абу Мусаб аль-Барнави, и таким образом, продемонстрировало свои растущие амбиции оказывать влияние на эту провинцию. Это, в свою очередь, привело к тому, что бывший руководитель провинции в последовавшие месяцы начал распространять видеозаписи, в которых он снова использовал прежнее название группировки Боко Харам.

Кроме этих провинций и анклавов ИГ, экспансия Халифата была исключительно фрагментированной. В регионе Сахель вооруженные группировки традиционно являются динамичными и изменчивыми, и есть давняя традиция формирования и распада спорадических альянсов в зависимости от того, что выгодно группировкам. Таким образом, некоторое число групп ИГ начали свое бытие как отколовшиеся от существующих групп АК. Однако, такие отколовшиеся группы существуют, только пока у них есть ясный интерес в использовании престижа бренда ИГ. Таким образом, были моменты, когда члены уходили из определенной группы АК и присягали на

6 SITE Intelligence, "Ansar Beit al-Maqdis Pledges Allegiance to the Islamic State," November 9, 2014. 
верность Багдади, только чтобы вернуться в свою бывшую группировку вскоре после этого. Подобным образом, есть примеры членов групп АК, которые заявляют о своей лояльности Багдади, и тем не менее остаются членами той же самой группы АК. Члены группы АК аль-Мурабитун, возглавляемой печально известным Мохтаром Белмохтар, присягнула на верность Багдади, оставаясь частью Мурабитун.

\section{АК в Северной Африке и Сахели: исторический обзор}

Приход ИГ в Северную Африку и Сахель, несомненно, породил определенное соперничество между ИГ и местными группами АК, хотя не обязательно - как это было в случае с Дерна - это приводило к вооруженной конфронтации. Однако разногласия между ИГ и АК не произрастают случайно на месте, а предопределены на самом высоком уровне идеологами Иг и АК, в том числе верховным руководителем АК, Айманом аль-Завахири. Теологические разногласия между ИГ и АК проявляются и в Северной Африке и Сахель, где до того, как появилось ИГ, существовали относительно сильные и хорошо консолидированные группы АК, АКИМ (АК в исламском Магрибе). АКИМ была среди наиболее верных приверженцев лидера АК аль-Завахири, без устали многократно подтверждающей свою поддержку руководству АК и вместе с Завахири бесконечное число раз подтверждало свою клятву на верность ряду руководителей движения Талибан.

В 2006 году АК создало опорный пункт в Северной Африке, когда вооруженная алжирская повстанческая группировка, СГМБ, начала официально сотрудничать с АК, что сразу привело к изменению названия на АКИМ. В 2006 СГМБ была ослаблена сражениями с алжирской армией и, по этой причине, момент оказался подходящим для присоединения к рядам АК с целью получить выгоду от престижа, которым пользовалась тогда эта группировка. До учреждения этой новой ветви АК в Алжире были предварительные разговоры и встречи между СГМБ и отделением АК в Ираке (АКИ), которое является одним из непосредственных предшественников Исламского государства. Лидеры СГМБ испытывали глубокое восхищение от знакового лидера АКИ, Абу Мусаб аль-Заркави, который в тот момент вел исключительно жестокую партизанскую войну с коалицией, возглавляемой США в Ираке. СГМБ послала большое число алжирских иностранных боевиков в Ирак, чтобы они воевали на стороне АКИ, и летом 2005 Заркави отплатил за эту поддержку убийством двух алжирских дипломатов в Багдаде. После смерти Заркави в июне 2006 года лидер АКИМ, Абделмалек Друкдел, принял имя Абу Мусаб в честь Заркави.

У АКИМ имелись давние связи с АК, уходящие в 1980-е, когда многие алжирцы отправлялись в Афганистан, чтобы принять участие в партизанской войне против Советского Союза. В начале 1990-х некоторые из алжирских «афганцев» вернулись в Алжир, где они внесли свой вклад в создание исламистского повстанческого движения ВИГ (Вооруженная ислам- 
ская группа), которое попыталось свергнуть алжирское правительство. В течение 1990-х ВИГ вела кровавую гражданскую войну против алжирского режима, и в целом против мусульман, которые не придерживались «прямого и узкого» теологического толкования ислама. Эти алжирские ветераны советско-афганской войны не только имели опыт партизанской войны, но и возвращаясь из Афганистана, принесли с собой очень строгую концепцию ислама. Их крайне насильственная стратегия дала, однако, обратный результат, заставив алжирскую общественность отвернуться от ВИГ. В то же время, в самой ВИГ появилось недовольство насильственным подходом группировки, и в 1998 году часть ведущих эмиров ВИГ откололась и создала вооруженную СГМБ, которая стала центром конфликта с алжирским государством.

В начале 2000-х алжирская армия подвергла СГМБ большому нажиму и это заставило группу начать расширяться на юг к Сахаре - в основном в северное Мали, но также и в Нигер и Мавританию. Там группировка вела прибыльный контрабандный бизнес и, располагая опытными партизанскими боевиками, смогла быстро интегрироваться в местную экономику и местное общество. Новоприбывшие боевики СГМБ женились на местных женщинах и щедро делились доходом от прибыльного контрабандного начинания. Около 2003 года СГМБ расширила сферу свой деятельности, начав брать иностранных заложников, которых выпускали на свободу за астрономический выкуп. Экспансия СГМБ в регион Сахара и Сахели дала группе стратегическую глубину в отношении ее основной деятельности, а именно в партизанской войне против алжирского государства. В 2006 году эти самые алжирские партизанские боевики влились в ряды АК и, в союзе с рядом местных группировок, летом 2012 года захватили все северное Мали, где они создали исламский эмират. В начале 2013 года в ситуацию в Мали вмешалась французская армия, заставив АКИМ и связанные с ней группы бежать. Некоторые высокопоставленные эмиры были убиты, но благодаря опыту партизанской войны, многие боевики осуществили организованное тактическое отступление в южную Ливию. Как раз в южной Ливии, через несколько дней после начала французской интервенции в Мали, опытный партизанский боевик, Мохтар Белмохтар, организовал большую операцию по взятию заложников, в результате которой были захвачены несколько сот заложников на заводе по переработке газа в Аменас в южном Алжире. Это нападение превратило Белмохтара из неизвестного лидера АКИМ в наиболее разыскиваемого преступника в Сахели.

\section{От раздробления к альянсу}

Вопрос состоит в том, что означало появление ИГ в Северной Африке и Сахели для закаленной в боях группировки АКИМ и других связанных с АК групп в регионе. Как было уже отмечено, Ливия - страна, в которой ИГ имеет наиболее сильное присутствие вне границ основного халифата в Ираке и Сирии. Однако Северная Африка/Сахель является регионом, в ко- 
тором также относительно хорошо утвердилась и АК. После ослабления АК в Пакистане и Йемене в результате воздушных ударов с использованием беспилотников, АКИМ является одной из немногих оставшихся групп АК, которые могут противостоять ИГ, и в то же время осуществлять злостные нападения против западных граждан и западных интересов в этом регионе. Можно задаться вопросом, переместился ли центр операций АК с востока на запад так, что в оперативном плане АКИМ перехватила инициативу у АК. Завахири все еще является бесспорным лидером, и это Завахири в коллаборации с другими идеологами АК определил идеологический путь группировки. Все-таки в оперативном плане АКИМ, предположительно, располагает большим потенциалом, чем начальный вариант АК в Пакистане и Афганистане. В ходе всех событий в 2015/2016 АКИМ наращивала интенсивность своей деятельности и осуществила большее число нападений против западных мишеней в регионе Сахели, чем когда-либо.

Рассматривая отношения между ИГ и АК в Северной Африке/Сахели, можно сказать, что в первую очередь ИГ создало опорные пункты в районах, где у АКИМ не было долгосрочного, глубоко укоренившегося присутствия. Таким образом, АКИМ успело сохранить свое влияние перед лицом ИГ и в определенной степени в сдерживании экспансии Халифата в Северную Африку. В настоящее время ИГ в северной Ливии ослаблено, но все еще присутствует там, и в меньшей степени, на Синае и в Нигерии. Примечательным для этих районов является факт, что они не входят в число основных районов операций АКИМ в Алжире и Сахели (Мали, Буркина Фасо, Нигер и южная Ливия).

ИГ попыталось закрепиться в тех странах Северной Африки, в которых в 2011 году были политические волнения, - то же самое можно сказать и о АК. Поэтому после Арабской весны в этих странах появились некоторые новые, связанные с АК группировки: Ансар аль-Шариат в Тунисе и Ливии, Ансар Бейт аль-Макдис в Египте и Укба бин Нафи в западной части Туниса на границе с Алжиром. За исключением Укба бин Нафи, которая была создана АКИМ, многие из этих новых групп АК впоследствии объединили свои силы с ИГ. Это, однако, не всегда происходило мирным путем. Основное противостояние имело место в Ливии, где и у обеих группировок имеется интерес в использовании хаотической политической ситуации. ИГ боролось с группами АК в Ливии, систематически уничтожая их лидеров. Этот метод оказался плодотворным в некоторых районах. Как было уже упомянуто, в Сирте местная группа Ансар аль-Шариат решила присоединиться к ИГ после того, как ИГ казнило местного лидера группы. Тем не менее, группа Ансар аль-Шариат все еще существует в Бенгази и регулярно совершает нападения, направленные против одного из ливийских правительств, чья ставка находится в Тобруке.

Однако, основным последствием экспансии ИГ на африканский континент является то, что АКИМ и множество свободно связанных с АК групп сформировали альянс, чтобы выступать единым фронтом против новопо- 
явившегося ИГ. До начала продвижения ИГ в этот регион, для групп АК в Северной Африке/Сахели были характерны бесконечные разногласия и соперничества, что приводило к расцеплению и раздроблению. Личные антагонизмы и разногласия по поводу власти и ресурсов регулярно приводили к отделению небольших фракций от АКИМ с целью создания своих собственных вооруженных групп (катиба). Некоторые из групп, которые в 2012 году создали эмират в северном Мали, были в числе этих отколовшихся от АКИМ групп, что не мешало им сотрудничать между собой в относительном мире и терпимости. К концу 2012 года опытный эмир АКИМ, Мохтар Белмохтар, откололся от АКИМ - хотя и не от основного ядра АК и создал собственную группу.

Перед лицом такого поведения со стороны АК отколовшиеся группы АК объединили свои силы. Это группы АК в регионе и отношения АКИМ с АК группами вне пределов Северной Африки/Сахели. После учреждения Халифата, АКИМ и АКАП (АК на Аравийском полуострове) весной 2014 года решили распространить совместное заявление, в котором они упрекали ИГ за убийство других мусульман и призывали мусульман в Сирии и Ираке выступить единым фронтом против ИГ. ${ }^{7}$ С тех пор АКИМ и АКАП в нескольких случаях делали совместные заявления, в которых они критиковали ИГ. В сентябре 2015 года Завахири смягчал свои слова, когда жестко критиковал Багдади и его псевдо-халифат, который, как он сказал, никоим образом не мог жить по законам Шариата. ${ }^{8}$ Вскоре после публикации выступления Завахири против ИГ, АКАП и АКИМ распространили совместное заявление, в котором они слово в слово повторили критики Завахири: Халифат не соответствует шариатскому праву, и ИГ совершает преступление против настоящего ислама, внося разногласия между мусульманами. ${ }^{9}$ С того момента это и есть основная претензия АКИМ против ИГ: они сеют раздоры между мусульманами и не испытывают угрызений, убивая братьев-мусульман. В двух случаях, дуо из АКИМ и АКАП было расширено до трио, когда эти группы распространили заявления вместе с Фронтом ан-Нусра. Это случилось после публичного объявления смерти лидера движения афганского Талибана, муллы Омара, в 2015 году, и после убийства его преемника, муллы Актара. Таким образом, в этих двух случаях объединялся конгломерат из трех больших групп АК, чтобы сделать совместное заявление.

7 SITE Intelligence, "AQAP and AQIM Release Joint Statement Condemning U.S.-led Alliance in Iraq and Syria, Urge Warring Factions to Unite," September 16, 2014.

8 SITE Intelligence, "Zawahiri Attacks Baghdadi, IS for Exporting Infighting from Iraq and Syria," September 9, 2015.

9 SITE Intelligence, "AQAP and AQIM Give Scathing Rebuke of IS in Joint Statement," November 1, 2015. 


\section{АК в Северной Африке и Сахели: джихадисты наносят ответный удар}

Это демонстративное братание групп АК в большой степени имеет отношение к рассматриваемому региону, где разные группы АК, которые раньше предпочитали идти разными путями, в течение 2015 года начали заявлять, что сейчас они объединяют свои силы, и более того, работают в сотрудничестве при осуществлении больших террористических нападений. Вопрос в том, однако, оказала ли влияние экспансия ИГ в этот регион на стратегию сближения групп АК и на их повышенный уровень активности в смысле нападений, направленных против иностранных интересов. Не конкуренция ли со стороны ИГ стала причиной смены стратегии групп АК и совершения большего количества и более разнообразных террористических нападений, чем прежде?

Вне всякого сомнения, что ИГ давно занимает ведущую позицию, когда речь идет о вербовке новых последователей. Долгое время иностранные боевики, которые отправлялись в Сирию, предпочитали присоединяться к ИГ, что до 2016 года приводило к успехам на поле боя, и в то же время - с помощью терактов в Париже и в Брюсселе - показало, что они способны наносить удары по целям в самом сердце европейских столиц. Таким образом, Халифат ИГ показал себя способным предложить своим последователям не только возможность принять участие в сражениях, но также принимать участие в жизни совершенно нового исламского общества и в распространении пропагандистских видеозаписей с применением крайних форм насилия. По сравнению с ИГ, АК выглядела как группа пенсионеров, которые когда-то, много лет назад, задавали тон, когда еще такие, ныне усопшие, но знаковые фигуры как Усама бен Ладен, Абу Мусаб аль-Заркави и Анвар аль-Авлаки были еще живыми.

Когда нынешний эмир АК, Айман аль-Завахири, распространяет трескучие звуковые файлы, проходят месяцы или даже годы, прежде чем они достигнут ушей общей публики. Эти звуковые файлы частично сопровождаются фотографическими изображениями Завахири - старого мужчины с длинной бородой и в очках. В отличие от чувственных оргий насилия ИГ с участием молодых, хорошо подготовленных боевиков, видеозаписи АК показывают пожилых господ, произносящих длинные теологические монологи, в которых они ставят задачи ИГ, ссылаясь на Коран, шариатское право и исламистские писания. Долгое время страницы западных СМИ были наполнены до отказа историями об ИГ, тогда как новости об АК можно было пересчитать по пальцам.

Таким образом, АК может предоставлять теологию, но ей приходится напрягаться, чтобы показать действия в форме успешных актов терроризма. Предположительно, это одна из причин, по которым АКИМ и все группы АК лезли друг другу на головы, хваля теракт против Шарли Эбро в Париже в январе 2015 года, который был осуществлен отделением АКАП 
Аль-Каиды. АК давно не осуществляла успешно то, о чем она постоянно мечтала, но не была способна совершить - зрелищное террористическое нападение на европейской земле.

Однако, в случае Северной Африки/Сахели, местные группы АК показали, что они все еще способны осуществлять нападения против западных мишеней. Верховный руководитель АКИМ, Абделмалек Друкдел, и бывший эмир АКИМ, Мохтар Белмохтар, предположительно являются мужчинами среднего возраста - т.е. им давно за сорок, - но это означает, что они являются опытными боевиками, которые были моджахедами в течение 25 лет и им удалось добиться почти невозможного - уцелеть. Этот обширный опыт означает, что они понимают всю подноготную повстанческого движения. Если АК хочет уцелеть в Северной Африке/Сахели, недостаточно пригнуться и ждать, пока ветер сдует феномен ИГ. АК нужно было показать, что она все еще располагает потенциалом планировать и совершать террористические нападения, и что в этой конкретной географической области у нее больший потенциал, чем у ИГ. В любом случае очевидно, что способность групп АК совершать террористические нападения усилилась с тех пор, как на сцену вышло ИГ в качестве джихадистской силы в регионе. В то же время, АКИМ приписывает себе преимущество совершать террористические нападения, которые демонстративно отличаются от терактов ИГ.

Основное отличие между этими двумя группировками состоит в том, кого они считают законными мишенями. Связанные с АК группы обвиняют ИГ в «пролитии крови мусульман» - например, когда ИГ начало совершать нападения на ан-Нусра в Сирии - в отличие от их собственной политики демонстративного направления своей агрессии против не-мусульман, которые незаконно находятся на мусульманской земле. В Северной Африке/ Сахели нападениям и похищениям подвергаются в основном жители западных стран, но нападения так же направлены и против военных, расположенных в регионе. Это алжирские или французские солдаты, принимающие участие в антитеррористических операциях в Сахели, или солдаты из миссии ООН по поддержанию мира в Мали, МИНУСМА.

АКИМ и связанные с ней группы не обязательно располагают потенциалом или имеют желание делать так, как делает ИГ, и осуществлять террористические нападения на европейской земле. Тем не менее, после теракта в Париже в ноябре 2015 года, ответственность за который приняло на себя ИГ, АКИМ решило продемонстрировать, что оно тоже способно совершать широкомасштабные теракты против иностранцев и западных интересов в Сахели. С ноября 2015 года АКИМ постоянно расширяло свою сферу деятельности, делая свои нападения непредсказуемыми. Например, коалиция групп, связанных и симпатизирующих АК, смогла осуществить три больших нападения на гостиницы в столицах Мали, Буркина Фасо и Берега Слоновой Кости, далеко за пределами своей традиционной области операций. Совершая эти нападения, вопросные группы АК специально хо- 
тели продемонстрировать, что их modus operandi [способ действий] отличается от способа действий ИГ, поскольку их мишенями являются исключительно иностранцы. В ходе совершения этих нападений они заставляли потенциальных жертв сказать, какой религии они придерживаются, с тем, чтобы случайно не убить мусульманина.

\section{ИГ в отступлении - АК в цветущем здравии?}

Как уже было сказано, Северная Африка - и, прежде всего, Ливия - была первостепенной целью Халифата, что касается территориальной экспансии. В мае 2016 года последний официальный представитель ИГ, Аднани, распространил тираду против США, в которой он говорит о Сирте как о городе, который имеет то же значение, что Мосул и Ракка: «Даже если вы захватите Мосул, Сирт и Ракку, и все наши города, вы все равно не победите нас». Это заявление показывает не только важное место Сирта в пропаганде ИГ, но и то, что военное счастье изменило ИГ, и что Халифат уже смирился с тем, что потеря территорий является реальной возможностью. Слово «экспансия» исчезло из официальной пропаганды ИГ.

Нет никакого сомнения, что сейчас ИГ находится под все возрастающим давлением - в Мосуле и Ракке, а в декабре 2016 года милиции Мисрата при поддержке США, Франции и Соединенного Королевства предположительно изгнали группировку из Сирта. ${ }^{10}$ Уже в августе боевые самолеты США бомбили цели в Сирте, и США и Франция в настоящее время имеют подразделения специальных сил на территории Ливии. Весной 2016 года ООН добилась успеха в составлении хрупкого национального правительства в Триполи, возглавляемого Файезом ас-Сарадж, и новое правительство объявило, что борьба против ИГ находится в числе его высших приоритетов. Остается вопрос, куда направятся боевики ИГ, вытесненные из Сирта. Уже имеются неподтвержденные сведения, что некоторые из этих боевиков начали отступать в сторону Сахели. Возможны потенциальные отголоски для миссии ООН МИНУСМА в Мали, или для таких стран Сахели, как Мали, Нигер и Буркина Фасо, где в настоящее время Франция проводит большую антитеррористическую операцию - операцию «Бархан». В соседнем Тунисе тоже очень обеспокоены тем, что может случиться, когда большое число тунисских иностранных боевиков, связанных с ИГ, вернутся в Тунис.

Все признаки указывают на то, что территориальная экспансия ИГ в Северную Африку гораздо более неустойчива, чем консолидированное присутствие АК в Северной Африке и в более широком регионе Сахели. АКИМ действовало в этом пустынном регионе многие десятилетия. Они знают эту область с изнанки, интегрированы в местную экономику и успели уцелеть при французских и алжирских контртеррористических операциях в 1990-х.

10 Frédéric Bobin, "Libye : l'Etat islamique vaincu à Syrte, après six mois de combats," Le Monde, December 5, 2016. 
Хотя АКИМ по традиции принимает участие в повстанческом движении против алжирского правительства, ее трансформация в отделение АК означала, что наряду с алжирским правительством ее мишенью стал «дальний враг», т.е. Запад. На первом месте в списке ее врагов находится старая колониальная сила, Франция. Однако ничто не подсказывает, что североафриканские группы АК намереваются совершать террористические нападения на европейской земле. Это не просто вопрос наличия потенциала, но зависит и от соображений о том, каковы будут последствия, если эти группы будут напрямую связаны с терактом в Европе. С другой стороны, они не воздерживаются от нападений на интересы Запада на их собственной территории, а именно в Северной Африке и Сахели. В этом плане они не отличаются от ИГ, которое все еще имеет амбицию совершать нападения на Западе.

\section{Об авторе}

Манни Крон, доктор, является старшим научным сотрудником Датского института международных исследований. Предметом ее текущего исследования является терроризм и контртерроризм в Европе, Северной Африке и Сахели. В число ее последних публикаций входят "Radicalization revisited," International Affairs 92:3 (2016) и "French interventionism in the postAmerican MENA-region: filling a void?," in Between Regional Autonomy and Intervention: New Conflict Dynamics in the Middle East and North Africa (DIIS, 2017). 